\title{
EXCITATION OF PLASMA BY ELECTRIC PULSES IN NEON MEDIUM
}

\author{
D.Yu. Zaleskyi, G.A. Krivonosov, G.V.Sotnikov \\ National Science Center “Kharkov Institute of Physics and Technology”, Kharksv, Ukraine \\ E-mail: zalesky@kipt.kharkov.ua
}

We studied characteristics of the neon plasma source excited in the atmosphere under the following conditions: gas pressure is about 2 Torr, rectangular pulses have an amplitude from 200 to $800 \mathrm{~V}$, pulse duration is from 0.2 to $10 \mu \mathrm{s}$, repetition rate is from 0.2 up to $1 \mathrm{kHz}$. There is a mode with a stable and unstable mode of existence of the plasma when the voltage on the electrodes of the plasma source varies from 800 to $350 \mathrm{~V}$ and from 350 to $250 \mathrm{~V}$ before the extinction of the plasma. The pulse from the PMT output in a steady state plasma has a decay of about $100 \mu \mathrm{s}$, the duration of which does not depend on the magnitude of the voltage, frequency and pulse duration. With a decrease in the supply voltage $U$, the pulse front duration with a photomultiplier is increased from 74 to $450 \mathrm{~ns}$. It is shown that a large neon plasma relaxation time of $100 \mu$ s compared with a beam pulse duration of $1 \ldots 2 \mu$ s allows only one time to change the phase of the accelerating field.

PACS: 84.40.Az, 84.90.+a

\section{INTRODUCTION}

To accelerate the witness part of the beam pulse by a wakefield, excited by the driver part of the beam pulse, witness particles must be shifted by $180^{\circ}$. To do this without splitting beam pulse, it is possible to use, for example, rotating magnets [1]; or introducing a small detuning between the frequency of the microwave generator and the bunch repetition frequency [2]. However, this method turned out to be ineffective due to the nonlarge transformation ratio, since a large number of bunches fell into the braking phase of the electromagnetic field. Therefore, another method was proposed in paper [3]: to change the phase of an electromagnetic wave generated by an electromagnetic klystron by an angle $\pi$ using a plasma phase inverter described in [4] for some part of the bunch pulse. Since in this case, in the dielectric structure, after the first part of the pulse, the next part of the bunches in the pulse will be in the accelerating phase of the wake wave.

In order to implement the possibility of solving this problem, a microwave plasma phase inverter circuit was proposed [3]. In this inverter, the phase shift was ensured by a mismatch of resonator resonance using a plasma source. This phase inverter should be included in the microwave path between the magnetron and the accelerator klystron.

To test the feasibility of this idea, a model of a phase inverter was developed and manufactured, the scheme of which is also presented in [3].

In the layout of a plasma phase inverter model, the microwave power from the generator, through the circulator, enters the resonator and, in the absence of plasma, enters the detector from which it enters the first channel of the oscillograph. When a pulsed voltage is applied from a generator of rectangular pulses, a plasma is generated in neon gas source, which mismatches the resonator. As a result, the microwave power begins to be reflected and through the circulator enters the reflected power detector and then to the second channel of the oscilloscope. Thus, in the case of resonance, the noninverted microwave power can be used in the first part of the beam propagation pulse, and in the case of resonator detuning, when plasma is generated, the inverted power is used in the second part.
As shown by experiments conducted on a microwave plasma phase inverter model [3], the most important element determining the efficiency of a phase inverter is the source of neon plasma. In a plasma phase inverter model, the plasma source is essentially a microwave power switch that should operate as soon as possible and detune the resonator. In order to achieve the necessary parameters for the combustion of neon plasma, additional studies were carried out which are presented in this work.

\section{EXPERIMENTAL SCHEME AND TECHNIQUE}

To carry out experiments on measuring the radiation of a neon plasma source, a stand was assembled; the scheme of which is presenred in Fig. 1.

The scheme works as follows. From a regulated DC voltage source, voltage from 250 to $800 \mathrm{~V}$ is applied to a capacitor (C). Capacitor was a film and a little inductive.

The MOS FET key (S) was controlled by a squarewave generator $(\mathrm{G})$, which used a measuring generator G5-54, which produces pulses with a repetition rate from several hertz to several kilohertz with a duration of $200 \mathrm{~ns}$ to $10 \mu \mathrm{s}$.

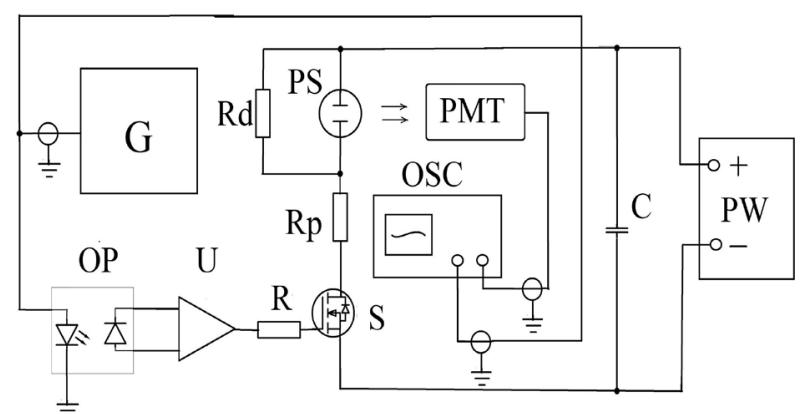

Fig. 1. The scheme of the stand for the study of the source of neon plasma using a photomultiplier; where $G$ is a square wave generator; $P W-D C$ power supply; PS - plasma source; PMT - photoelectronic multiplier (PMT); OSC is a digital oscilloscope,

$S$ is a semiconductor key-MOS FET;

$O P$ - optocoupler; U - MOS FET driver;

$C$-capacitor; $R, R p, R d$-current limiting, protective and discharge resistors 
The pulses from the generator $(\mathrm{G})$ to the key $(\mathrm{S})$ are delivered through the optocoupler (OP) and the driver (U). The optocoupler provides galvanic isolation of the generator of square-wave pulses from the pulse formation circuit of a neon plasma source. This reduces the mutual influence of the circuits and the appearance of parasitic noise pickups when measuring the shape of voltages and currents and setting up the circuit. The driver (U) provides current amplification for fast charging of the parasitic capacitance of the gate of the MOS FET key (S), thereby ensuring quick closing and opening of the key $(\mathrm{S})$.

When opening the key $(\mathrm{S})$, the voltage is equal to the supply voltage from the capacitor (C) through the protective resistance Rp to the neon plasma source (PS). If the voltage and time parameters are sufficient to ignite the plasma at the PMT output (PMT), the voltage is proportional to the plasma emission value (PS).

The source of neon plasma (PS) was a miniature glass sealed balloon filled with neon with a pressure of about $2 \mathrm{~mm} \mathrm{Hg}$. The electrodes to which voltage was applied were a flat circular cathode and a wire ring anode located above it. Plasma when visually observed when applying constant voltage on the plasma source occupied the volume almost from the outer surface of the cathode to the anode.

The FEU-68 was used as a photoelectron multiplier (PMT) in the experimental setup. To correctly display the pulses in the passport scheme of the PMT, additional capacitors were added, according to [5].

To check the display of the pulse shape from the PMT output, instead of a plasma source, an LED was turned on. The measurement results are shown in the oscillograms shown in Fig. 2.
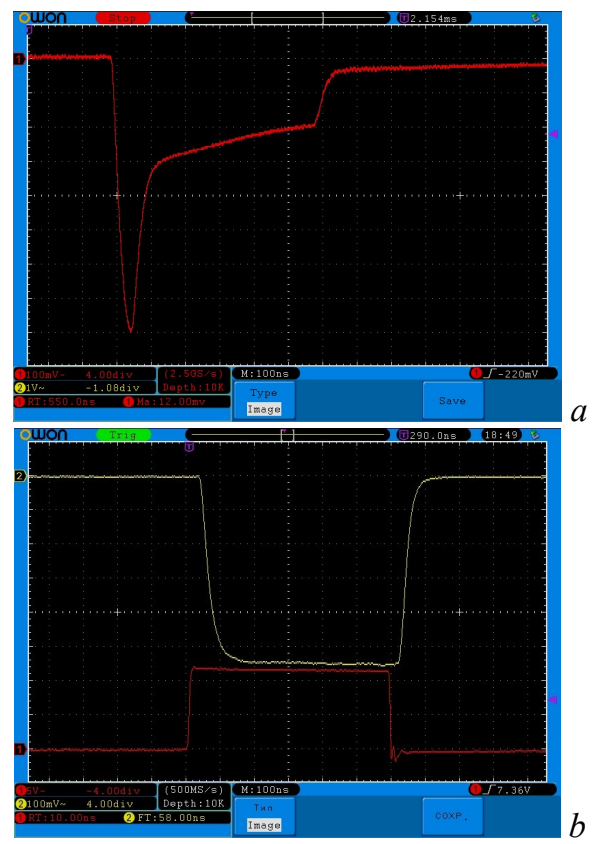

Fig. 2. Pulse shape when measuring the radiation of the LED, where a) pulse shape from the output of the photomultiplier without corrective capacitors; b) pulse shape with corrective capacitances: in the top is the voltage with the output of the PMT, in the bottom is the voltage supplied to the light-diode

\section{RESULTS OF MEASUREMENTS}

As shown by measurements at the output of the PMT (the first example for the applied voltage of $700 \mathrm{~V}$ is shown in Fig. 3) in the voltage form the presence of a high-frequency component at the pulse front (oscillogram "a") and a low-frequency pulse component in the decay part of the pulse (oscillogram "b") is observed.

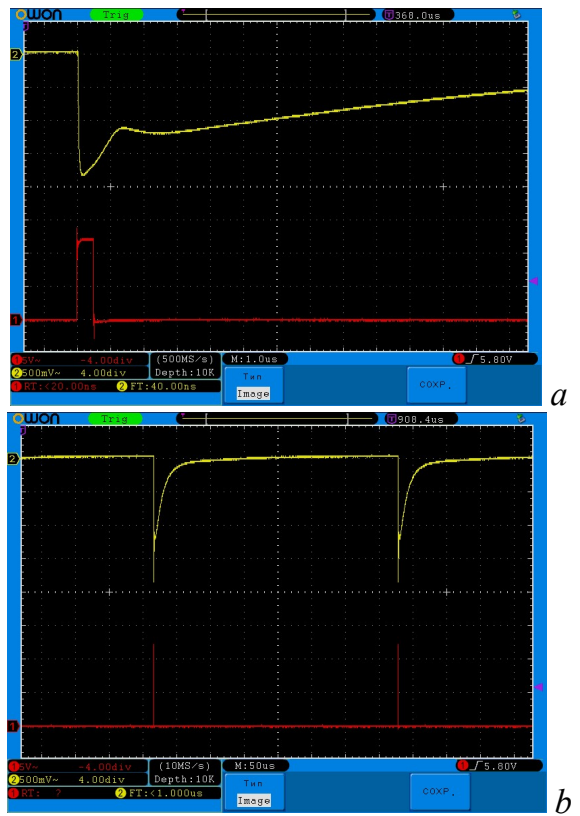

Fig. 3. Oscillograms of a signal from a photomultiplier for oscilloscope sweeps: a) $1 \mu \mathrm{s} / \mathrm{div}$. and b) $50 \mu \mathrm{s} / \mathrm{div}$.

The voltage at the plasma source is $700 \mathrm{~V}$

High-frequency part has approximately the same duration as the voltage pulse supplied to the neon plasma source (line 1), but has a smoother shape. The duration of the fall-off of the low-frequency component reaches a duration of $100 \mu \mathrm{s}$ and practically does not change when the voltage $(U)$, frequency $(F)$ and duration $(\tau)$ of pulses applied to a neon plasma source are changed.

When analyzing the obtained oscillograms, the following tendencies of changing the pulse shape with decreasing voltage (U) were found. From 800 to $500 \mathrm{~V}$, the pulse shape remains almost constant. Further, as the voltage decreases, the pulse front from the PMT output increases, the amplitudes of the high-frequency component almost do not change, and the amplitude of the low frequency component falls. Also during the experiments, the following tendencies in the behavior of neon plasma were discovered. At the duration of $500 \mathrm{~ns}$ and a pulse repetition rate of $1 \mathrm{kHz}$ with an increase in the supply voltage, the plasma arises at a voltage of about $350 \mathrm{~V}$, and goes out when the voltage decreases to $250 \mathrm{~V}$. It was found that if the voltage is less than $350 \mathrm{~V}$, then the plasma does not appear and behaves unstably. The same trends are observed when decreasing in the repetition rate $(\mathrm{F})$ and the duration $(\tau)$ of the pulses, but already with a higher voltage.

One of the regimes of the neon plasma state in the unstable mode at constant $(\mathrm{U})$, when decreasing frequency $(F)$, can be seen on the oscillograms shown in Fig. 4,a,b,c. 

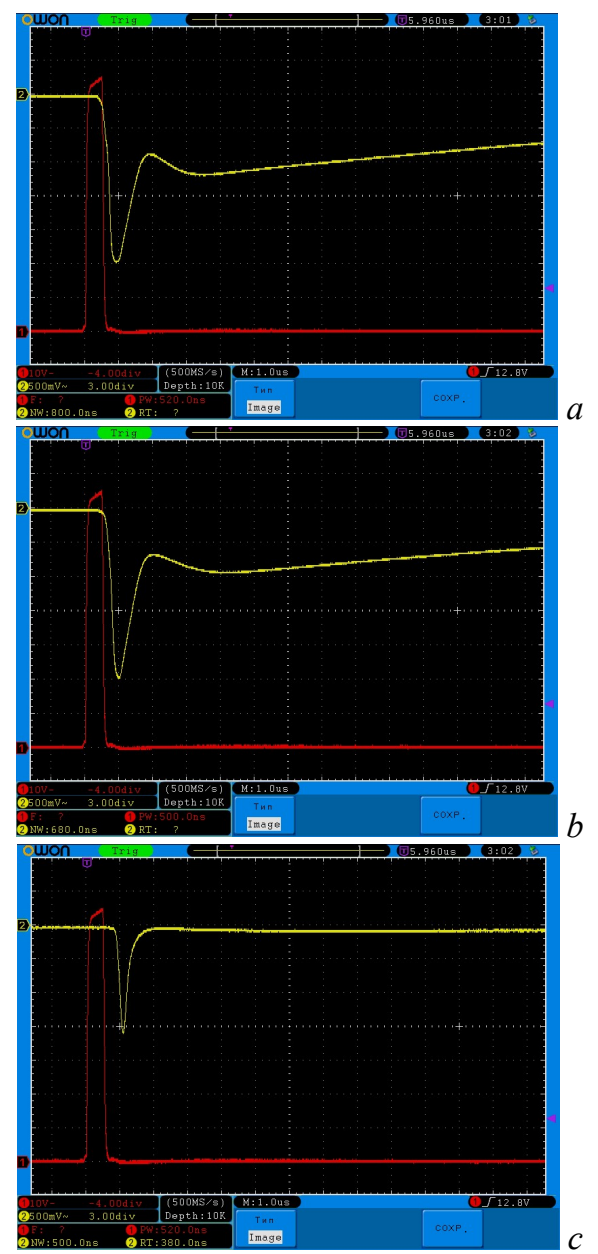

Fig. 4. Oscillograms of a signal from a photomultiplier output for a frequency: a) $400 \mathrm{~Hz}$; b) $300 \mathrm{~Hz}$;

c) $200 \mathrm{~Hz}$. The voltage (U) is $700 \mathrm{~V}$

and the pulse duration is $500 \mathrm{~ns}$

As follows from presented oscillograms, both with a decrease in the voltage applied to the discharge (U) or with a decrease in frequency $(\mathrm{F})$, at the beginning, only a decrease in the low-frequency part of the pulse (decay) is observed with a constant amplitude of the front (high-frequency) part of the pulse. At the next decrease in $\mathrm{U}$ ot $\mathrm{F}$ a complete absence of low-frequency is obsereved (the oscillogram c)). After that, with decreasing (F) until the plasma disappears, the amplitude of the entire pulse begins to decrease. The pulse front of the oscillograms in Fig 4,a,b,c is 180, 240, and 450 ns.

Oscillograms illustrating the change in the front depending on the voltage in the steady state of the neon plasma are shown in Fig. 5.

As can be seen from the oscillograms in Fig. 5, in the steady mode the same as in the unstable mode is observed, the tendency with deterioration of the plasma existence conditions, that is, the decrease of the voltage $\mathrm{U}$, the pulse front increases from 74 to $124 \mathrm{~ns}$.

Analyzing the data of Figs. 4 and 5, we can conclude that with the deterioration of the conditions of existence of the plasma, the pulse front increases, which indicates an increase in the plasma ionization time.
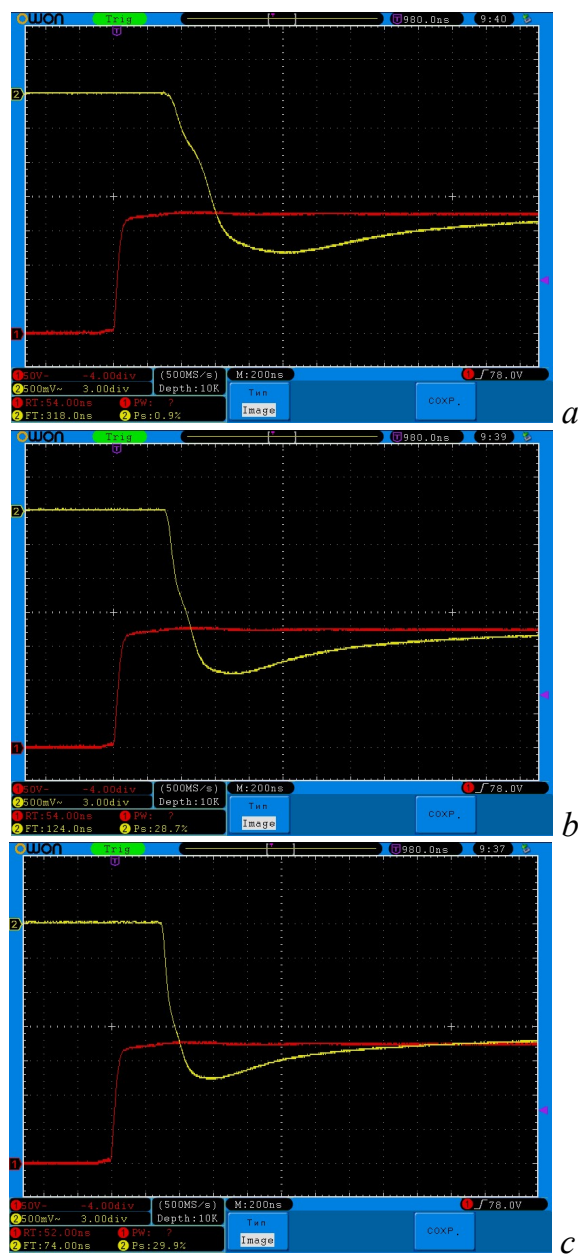

Fig. 5. Oscillograms of a signal from the photomultiplier output for voltage (U): a) $400 \mathrm{~V}$; b) $600 \mathrm{~V}$; c) $800 \mathrm{~V}$. At a repetition frequency $(F)$ of $1 \mathrm{kHz}$ and a pulse duration ( $\tau$ ) of $10 \mu \mathrm{s}$

\section{CONCLUSIONS}

Analysis of the results of the experiments makes it possible to draw the following conclusions

The state of the neon plasma, depending on the voltage at the source, can be stable and unstable. The transition from a steady state to an unstable plasma state is observed with decreasing voltage, repetition rate, or pulse duration. Plasma excitation time (pulse front) decreases with increasing voltage amplitude applied to the neon plasma source The relaxation time of a plasma (pulse decay) in its stable state does not depend on the voltage at the electrodes of the plasma source, the duration and pulse repetition frequency. It is equal about $100 \mu$ s. Thus, a large relaxation time compared with the duration of the pulse of the electron beam allows only one time to change the phase of the accelerating field.

Work was partially supported by the Ukrainian budget program "Support for the most important directions of scientific researches" (КПКВК 6541230).

\section{REFERENCES}

1. V.A. Vishnyakov, V.V. Zakutin, V.A. Kushnir, et al. Experimental investigation of an obtaining of high accelerating fields and the acceleration of beam of linear resonance accelerator in the passive resonator 
system // J. Technical Physics. 1987, v. 57, № 8, p. $1549-1554$.

2. G.P. Berezina, A.E. Yegorov, G.A. Krivonosov, et al. Electron bunches acceleration at detuning bunch repetition frequency and frequency of wakefield excited in a dielectric structure // Problems of Atomic Science and Technology. Series "Nuclear Physics Investigations”. 2015, № 6, p. 56-59.

3. D.Yu. Zaleskyi, G.A. Krivonosov, G.V. Sotnikov. The model of microwave phase inverter controlled by a neon plasma source // Problems of Atomic Sci- ence and Technology. Series "Nuclear Physics Investigations”. 2018, № 3, p. 58-62.

4. A.L. Vikharev, A.L. Vikharev, A.M. Gorbachev, et al. Millimeter-wave electron-beam-switched resonance phase shifter // Technical Physics. 2009, v. 54, № 11, p. 1648-1654.

5. N.O. Chechik, S.M. FineStain, and T.M. Lifshits. Electronic multipliers. Moskow, 1957.

Article received 11.06.2019

\section{ВОЗБУЖДЕНИЕ ПЛАЗМЫ ЭЛЕКТРИЧЕСКИМИ ИМПУЛЬСАМИ В СРЕДЕ НЕОНА}

\section{Д.Ю. Залеский, Г.А. Кривоносов, Г.В Сотников}

Проведены исследования характеристик неонового источника плазмы, возбуждаемого прямоугольными импульсами с амплитудой напряжения от 200 до $800 \mathrm{~B}$, длительностью от 0,2 до 10 мкс и частотой от 0,2 до 1 кГц при давлении газа в камере источника плазмы порядка 2 Торр. Исследования показали, что .наблюдаются режимы с устойчивым и неустойчивым состоянием плазмы при изменении напряжения на электродах источника плазмы от 800 до 350 В и от 350 до 250 В до погасания плазмы. Импульс с выхода ФЭУ в устойчивом состоянии плазмы имеет спад около 100 мкс, длительность которого не зависит от величины напряжения, частоты и длительности импульса. При уменьшении питающего напряжения длительность фронта импульса с ФЭУ увеличивается с 74 до 450 нс. Показано, что большое время релаксации неоновой плазмы 100 мкс по сравнению с длительностью импульса (1..2) мкс следования электронного пучка позволяет только один раз менять фазу ускоряющего поля.

\section{ЗБУДЖЕННЯ ПЛАЗМИ ЕЛЕКТРИЧНИМИ ІМПУЛЬСАМИ В СЕРЕДОВИЩІ НЕОНУ \\ Д.Ю. Залеський, Г.А. Кривоносов, Г.В. Сотніков}

Проведено дослідження характеристик неонового джерела плазми, порушуваного прямокутними імпульсами 3 амплітудою напруги від 200 до 800 У, тривалістю від 0,2 до 10 мкс і частотою від 0,2 до 1 кГц при тиску газу в камері джерела плазми порядку 2 Торр. Дослідження показали, що .спостерігаються режими зі стійким і нестійким станами плазми при зміні напруги на електродах джерела плазми від 800 до 350 В и від 350 до 250 В до загасання плазми. Імпульс із виходу ФЕП в стійкому стані плазми має спад близько 100 мкс, тривалість якого не залежить від величини напруги, частоти і тривалості імпульсу. При зменшенні живільної напруги тривалість фронту імпульсу з ФЕП збільшується з 74 до 450 нс. Показано, що великий час релаксації неонової плазми у порівнянні із тривалістю імпульсу (1..2) мкс проходження електронного пучка дозволяє тільки один раз змінити фазу прискорювального поля. 